Article

\title{
The Impact of Different Factors on the Quality and Volatile Organic Compounds Profile in "Bryndza" Cheese
}

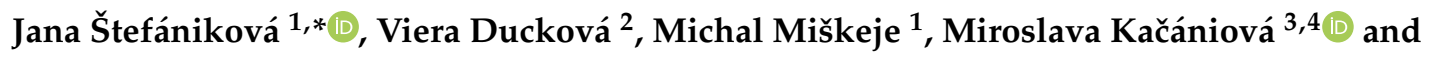 \\ Margita Čanigová ${ }^{2}$ \\ 1 AgroBioTech Research Centre, Slovak University of Agriculture in Nitra, Tr. A. Hlinku 2, \\ 94976 Nitra, Slovakia; michal.miskeje@uniag.sk \\ 2 Department of Technology and Quality of Animal Products, Faculty of Biotechnology and Food Sciences, \\ Slovak University of Agriculture in Nitra, Tr. A. Hlinku 2, 94976 Nitra, Slovakia; \\ viera.duckova@uniag.sk (V.D.); margita.canigova@uniag.sk (M.Č.) \\ 3 Department of Fruit Science, Viticulture and Enology, Faculty of Horticulture and Landscape Engineering, \\ Slovak University of Agriculture in Nitra, Tr. A. Hlinku 2, 94976 Nitra, Slovakia; \\ miroslava.kacaniova@gmail.com \\ 4 Department of Bioenergy, Food Technology and Microbiology, Institute of Food Technology and Nutrition, \\ University of Rzeszow, Cwiklinkiej 1, 35601 Rzeszow, Poland \\ * Correspondence: jana.stefanikova@uniag.sk; Tel.: +421-376-414-911
}

Received: 31 July 2020; Accepted: 27 August 2020; Published: 29 August 2020

check for updates

\begin{abstract}
The aim of this study was to evaluate the influence of different factors on the basic physicochemical and microbiological parameters, as well as volatile organic compounds of traditionally (farm) and industrially produced "bryndza" cheese. The samples were obtained from eight producers in different areas of Slovakia during the ewe's milk production season, from May to September. The physicochemical parameters set by the legislation were monitored by reference methods. The "bryndza" cheese microbiota was determined by using the plate cultivation method. There was analysis of volatile organic compounds carried out by electronic nose, as well as gas chromatography mass spectrometry. Seasonality and production technology (traditional and industrial ones) are the main factors that affect the standard quality of "bryndza" cheese. Lactic acid bacteria were dominated from bacterial microbiota, mostly presumptive lactococci, followed presumptive lactobacilli and enterococci. The numbers of coliform bacteria were higher in traditionally produced "bryndza" cheese than in industrially produced "bryndza" cheese. The presence of Dipodascus geotrichum was detected in all samples. There were key volatile organic compounds such as ethyl acetate, isoamyl acetate, 2-butanone, hexanoic acid, D-limonene, and 2,3-butanedione. The statistically significant differences were found among "bryndza" cheese samples and these differences were connected with the type of milk and dairies.
\end{abstract}

Keywords: "bryndza" cheese; electronic nose; gas chromatography; volatile organic compounds; microbiota

\section{Introduction}

The traditional Slovak ewe's milk product is "bryndza" cheese or local cheese "oštiepok" [1,2]. Slovak "bryndza" cheese is natural, white, spreadable cheese, and manufactured by the traditional method. It is recognized in the European Union by Protected Geographic Indication (PGI) status as cheese produced in specified mountainous regions of Slovakia [3], where unpasteurized ewe's milk is processed immediately after milking by renneting at $29-31^{\circ} \mathrm{C}$ for $30 \mathrm{~min}$, using chymosin or 
chymosin-identical rennet [4], and the cheese grain is formed into the lump cheese. The lump cheese is drained at $18-22{ }^{\circ} \mathrm{C}$ for $24 \mathrm{~h}$ and is left to ripen for 3 days at $18-22{ }^{\circ} \mathrm{C}$. The production process continues by further ripening at $12-15^{\circ} \mathrm{C}$ for $7-10$ days. Ripened ewe's lump cheese is processed by removing the crust, pressed to remove whey and milled with salt solution (4-6\% w/w), in order to obtain the specific creamy texture of "bryndza". The mountainous regions of Slovakia differ in altitude, climate, geological, and vegetation profile and there are some scientific evidences about variability of "bryndza" cheese. There are several studies related to the variability of "bryndza" that are lack of common characteristics of this Slovak cheese [5]. Ewe's cheese represents a matrix with a specific composition which reflected ewe's milk, as well as different autochthonous non-starter lactic acid bacteria (NSLAB) that produce typical aroma profile of ewe's lump cheese, barrelled ewe's cheese and "bryndza" cheese [4,5]. Kacaniova et al. [6] identified 870 isolates from coliforms, enterococci, lactic acid bacteria (LAB) and yeasts in Slovak "bryndza" cheese by MALDI-TOF MS profiling. The most frequently identified species of gram-negative bacteria were Hafnia alvei and Klebsiella oxytoca. The most frequently identified species of gram-positive bacteria were Lactococcus lactis and Lactobacillus paracasei. LAB group was represented by Lactobacillus, Lactococcus and Pediococcus. Pangallo et al. [7] confirmed that microorganisms that belong to the species Galactomyces candidus and Yarrowia lipolitica as typical yeasts of "bryndza" cheese.

Numerous volatile organic compounds (VOCs) of cheese, including raw milk-based ewe's cheese are formed by proteolysis and by the subsequent transformation of amino acids [8] to $\alpha$-keto acids [9]. There has been two different major pathways of amino acid degradation identified in L. lactis [10] so far. The first pathway is initiated by an elimination reaction of methionine catalyzed by amino acid lyases, and leading to major sulfur aroma compounds [11,12]. The second pathway is initiated by a transamination reaction catalyzed by aminotransferases and resulting especially in volatile amino acids, branched chain amino acids and methionine $[13,14]$. The resulting $\alpha$-ketoacids are then degraded to aldehydes, alcohols, carboxylic acids, esters, methanethiol and other sulfur compounds. The most of these compounds are produced by enzymatic degradation, but some of them are the result of chemical degradation in oxidation $[15,16]$. The characteristics of cheese (flavor, texture, and color) are influenced by the free fatty acids (FFAs) of the milk, the main products of enzymatic hydrolysis of triacylglycerides by esterases and lipases [17]. The goat and ewe's milk contain high levels of short-and medium-chain fatty acids, in comparison with cow's milk. Specifically, short-chain fatty acids are very important because of their low perception thresholds. Some studies point out that milk fatty acid content could be a distinguishing clue between breeds [18]. Partial lipolysis occurs in "bryndza" cheese during its ripening. Additionally, FFAs may participate in catabolic reactions and cause an increase in the amount of aroma compounds such as methyl ketones, esters, alkanes, lactones, aldehydes, and secondary alcohols [19].

VOCs are usually analyzed by gas chromatography (GC) after the extraction or pre-concentration of the volatile fraction. The most exhaustive methods for this purpose are high vacuum distillation (HVT), solvent-assisted aroma evaporation (SAFE) or solid phase microextraction (SPME) [20,21] combined with headspace. Sádecká et al. [20] used SPME with gas chromatography-olfactometry (GC-O) for the determination of volatile odorants in May "bryndza" cheese. There were 25 olfactometric responses from the groups of alcohols, aldehydes, esters, ketones, fatty acids, and hydrocarbons recorded, depending on the degree of cheese maturation and from a GC-O point of view. There was an electronic nose (e-nose) based on a gas chromatography used for aroma profile determination of soft, steamed cheese called "parenica" from Slovakia in a previous study [22].

The aim of this study was to obtain microbiological parameters and parallel information of principal VOCs in "bryndza" cheese produced by 8 Slovak producers with the use of e-nose and a GC-MS. The other goal was to prove a significant impact of the dairies and the type of milk on the content of VOCs in "bryndza" cheese. 


\section{Materials and Methods}

\subsection{Bryndza Cheese Samples}

The samples of "bryndza" cheese were obtained from 8 different producers in Slovakia (B1-8) and detailed characteristics were got from the packages (Table 1). Bryndza cheese samples B1, B2, B4, B6, and B7 were produced in the farm dairies and the samples B3, B5, and B8 were produced in the industrial dairies. All samples were collected monthly from May 2019 to September 2019. Each sample (500 g) was transported to the laboratory at a temperature of $6{ }^{\circ} \mathrm{C}$. There were physicochemical parameters, microbiological quality and volatile organic compounds within one day after the delivery determined in the representative samples. A total of 40 samples were analyzed.

Table 1. Characterization of analyzed bryndza cheese samples.

\begin{tabular}{|c|c|c|c|c|c|c|c|c|}
\hline & B1 & B2 & B3 & B4 & B5 & B6 & B7 & B8 \\
\hline Ewe's Milk & $100 \%$ & $100 \%$ & $\min 50 \%$ & $100 \%$ & $\begin{array}{c}\min 50 \% \\
\text { or } 100 \%\end{array}$ & $100 \%$ & $100 \%$ & $\min 50 \%$ \\
\hline $\begin{array}{c}\text { Raw/Pasteurized } \\
\text { Milk }\end{array}$ & $\mathrm{R}$ & $\mathrm{R}$ & $\begin{array}{l}\text { ewes' R } \\
\text { cows' P }\end{array}$ & $\mathrm{R}$ & $\mathrm{P}$ & $\mathrm{R}$ & $\mathrm{R}$ & $\mathrm{P}$ \\
\hline Dry Matter & $\begin{array}{l}\min \\
44 \%\end{array}$ & UL & $\begin{array}{l}\min \\
44 \%\end{array}$ & UL & $\begin{array}{c}\min 44 \% \\
48 \%\end{array}$ & $44 \%$ & $\begin{array}{l}\min \\
48 \%\end{array}$ & $\begin{array}{l}\min \\
44 \%\end{array}$ \\
\hline Fat in Dry Matter & $\begin{array}{l}\min \\
48 \%\end{array}$ & UL & $\begin{array}{l}\min \\
48 \%\end{array}$ & UL & $\begin{array}{l}\min \\
48 \%\end{array}$ & $48 \%$ & $\begin{array}{l}\min \\
48 \%\end{array}$ & $\begin{array}{l}\min \\
48 \%\end{array}$ \\
\hline $\mathrm{NaCl}$ & $\begin{array}{l}\max \\
2.5 \%\end{array}$ & $\begin{array}{l}\max \\
2.5 \%\end{array}$ & $\begin{array}{l}\max \\
2.5 \%\end{array}$ & UL & $\begin{array}{l}\max \\
2.5 \%\end{array}$ & $\begin{array}{l}\max \\
2 \%\end{array}$ & $\begin{array}{l}\max \\
2.5 \%\end{array}$ & $1.9 \%$ \\
\hline $\begin{array}{c}\text { Producing Area of } \\
\text { Slovakia }\end{array}$ & middle & middle & middle & west & middle & east & middle & middle \\
\hline Package & $\begin{array}{c}\text { plastic } \\
\text { foil }\end{array}$ & $\begin{array}{c}\text { plastic } \\
\text { foil }\end{array}$ & $\begin{array}{l}\text { plastic } \\
\text { foil }\end{array}$ & $\begin{array}{c}\text { plastic } \\
\text { foil }\end{array}$ & $\begin{array}{l}\text { paper }+ \\
\text { aluminium } \\
\text { foil }\end{array}$ & $\begin{array}{c}\text { plastic } \\
\text { container }\end{array}$ & $\begin{array}{c}\text { plastic } \\
\text { foil }\end{array}$ & $\begin{array}{c}\text { plastic } \\
\text { foil }\end{array}$ \\
\hline
\end{tabular}

UL-unlabeled.

\subsection{Determination of Physicochemical Properties}

Fat was determined according to ISO 3433:2008 [23], dry matter according to ISO 5534:2004 [24]. Fat in dry matter was determined by calculation. $\mathrm{pH}$ was determined by $\mathrm{pH}$ meter Orion Star A211 (Thermo scientific, Renfrew, UK). The analysis of all physicochemical parameters were replicated three times.

\subsection{Microbiological Analysis}

Ten grams of each sample from each cheese group were put into a sterile bag under aseptic conditions and homogenized in $90 \mathrm{~mL}$ of sterile peptone/saline solution $(0.87 \%)$ for 2 min in a Stomacher bagmixer blender (Interscience, Saint-Nom-la-Bretèche, France). Decimal dilutions were prepared according to ISO 6887-5 (2010) [25].

Coliform bacteria (CB) were determined according to ISO 4832:2006 [26]. Yeasts and moulds (Y) were determined according to ISO 21527-1:2010 [27]. Presumptive lactobacilli (PLb) were determined by enumeration of colonies after anaerobic cultivation on de Man, Rogosa and Sharpe (MRS) agar (HiMedia, Maharashtra, India) for $72 \mathrm{~h}$ at the temperature of $37^{\circ} \mathrm{C}$. Presumptive lactococci (PL) were determined by enumeration of colonies after aerobic cultivation on M17 agar (HiMedia) for $72 \mathrm{~h}$ at the temperature of $30{ }^{\circ} \mathrm{C}$. Enterococci (E) were determined by enumeration of colonies after aerobic cultivation on Bile Esculine Azide (BEA) agar (Biokar, Allonne, France) for $24 \mathrm{~h}$ at the temperature of $37^{\circ} \mathrm{C}$ according to ISO 27205:2010 [28]. Microbial counts were performed in triplicate.

\subsection{Analysis of Volatile Organic Compounds by Electronic Nose}

The previously described electronic nose (e-nose) (Heracles II, Alpha M.O.S., Toulouse, France) method [22] was used for volatile organic compounds analysis. There was $2.5 \mathrm{~g}$ of sample incubated statically in a $20 \mathrm{~mL}$ vial in a thermostat block at the temperature of $50{ }^{\circ} \mathrm{C}$ for $15 \mathrm{~min}$ (Autosampler, Alpha 
M.O.S.) and $5 \mathrm{~mL}$ volume of the headspace gaseous compounds was withdrawn using a headspace autosampler syringe and dispensed into the e-nose injector for each analysis. The identification of the compounds was performed by matching the measured peaks with Kovats retention indices with NIST library (The National Institute of Standards and Technology library) $(>50 \%)$ by software Alpha Soft V14 (Alpha M.O.S.). Each sample was weighed and placed in three different vials, each one was analyzed once.

\subsection{Analysis of Volatile Organic Compounds by Gas Chromatography Mass Spectrometry}

The head-space solid-phase microextraction (HS-SPME) method previously described [20] was used for sample extraction in a modified version. The amount of $2.5 \mathrm{~g}$ of sample was incubated statically in a $20 \mathrm{~mL}$ vial in a thermostat block at the temperature of $50{ }^{\circ} \mathrm{C}$ for $30 \mathrm{~min}$ (CombiPal automated sample injector 120, CTC Analytics AG, Zwingen, Switzerland), with an SPME fibre (1 cm; $50 / 30 \mu \mathrm{m}$ DVB/CAR/PDMS) (Supelco, Bellefonte, PA, USA) placed in the CombiPal for each analysis. The fibre was initially conditioned by heating in the SPME Fiber Cleaning and Conditioning Station (placed in the CombiPal) at the temperature of $270^{\circ} \mathrm{C}$ for $1 \mathrm{~h}$. SPME extracts were desorbed in the GC injector at the temperature of $250^{\circ} \mathrm{C}$ for $1 \mathrm{~min}$ and the fibre was cleaned in SPME Fiber Cleaning and Conditioning Station at $230^{\circ} \mathrm{C}$ for $10 \mathrm{~min}$.

The relative content (expressed in percentage) of samples was determined by gas chromatography mass spectrometry (GC 7890B-MS 5977A) (Agilent Technologies Inc., Santa Clara, CA, USA) equipped with column DB-WAXms $(30 \mathrm{~m} \times 0.32 \mathrm{~mm} \times 0.25 \mu \mathrm{m}$; Agilent Technologies Inc., Santa Clara, CA, USA) operating with a temperature program and MS conditions [20]. The identification of compounds was carried out by comparing mass spectra (over 80\% match) with a commercial database NIST®2017, and Wiley library, retention times of reference standards (ethyl acetate, hexanoic acid and isoamyl alcohol) comparison of data on occurrence in cheese from Slovakia with literature $[5,20,29]$. The relative content of determined compounds was calculated by dividing individual peak area by the total area of all peaks. Peaks under $1 \%$ were not counted. Each sample was measured in triplicate.

\subsection{Statistical Analysis}

Compounds identified by e-nose with a discriminant $\mathrm{D}>0.900$ were selected as significant sensors, based on which the PCA (Principal Component Analysis) was made by Alpha Soft V14 (Alpha M.O.S.) software.

The STATGRAPHICS Centurion (C StatPoint Technologies, Inc., Warrenton, VA, USA) and GraphPad Prism 6.01 (GraphPad Software Incorporated, San Diego, CA, USA) were used for statistical physicochemical, microbiological and GC-MS analysis. The ANOVA method complemented by the Test of Tukey's Multiple Comparison Test and unpair t-test with a value of $p<0.05$ was applied.

\section{Results}

\subsection{Physicochemical Properties of "Bryndza" Cheese}

The results of the physicochemical parameters of "bryndza" cheese are shown in Table 2. The content of dry matter and fat in the dry matter are the parameters of bryndza cheese prescribed by the legislation [30]. The variability of "bryndza" cheese dry matter content ranged from $2.34 \%$ to $5.19 \%$ for farm dairies (B1, B2, B4, B6, B7) samples and from $2.37 \%$ to $5.52 \%$ for industrial dairies (B3, B5, B8) ones. Higher coefficients of variation were found in the parameter of fat in dry matter, which ranged from $1.75 \%$ to $7.98 \%$ in "bryndza" cheese from farm dairies and from $2.71 \%$ to $9.77 \%$ in samples from industrial dairies. Mixed "bryndza" cheese (B3, B8) samples had the lowest average fat content. The $\mathrm{pH}$ value of bryndza cheese as an indicator of ripening was more stable in "bryndza" cheese from industrial dairies (coefficient of variation ranged from $0.99 \%$ to $1.69 \%$ ) than in "bryndza" cheese from farm dairies (coefficient of variation ranged from $1.22 \%$ to $3.82 \%$ ). 
Table 2. Physicochemical properties of bryndza cheese (average values, means \pm SD).

\begin{tabular}{|c|c|c|c|c|c|c|c|c|}
\hline & B1 & B2 & B3 & B4 & B5 & B6 & B7 & B8 \\
\hline $\mathrm{F}(\%)$ & $24.8 \pm 2.1$ & $24.9 \pm 1.6$ & $19.4 \pm 2.5$ & $24.8 \pm 1.3$ & $24.3 \pm 3.3$ & $26.4 \pm 0.4$ & $26.3 \pm 3.1$ & $22.4 \pm 0.5$ \\
\hline DM (\%) & $47.7 \pm 1.1$ & $48.9 \pm 1.4$ & $42.5 \pm 2.0$ & $54.1 \pm 2.8$ & $49.3 \pm 2.7$ & $52.0 \pm 1.4$ & $53.1 \pm 2.2$ & $45.5 \pm 1.1$ \\
\hline FDM (\%) & $51.8 \pm 3.4$ & $50.9 \pm 2.2$ & $45.6 \pm 4.5$ & $45.8 \pm 1.4$ & $49.1 \pm 3.9$ & $50.8 \pm 0.9$ & $49.5 \pm 4.0$ & $49.4 \pm 1.3$ \\
\hline $\mathrm{pH}$ & $5.24 \pm 0.2$ & $5.09 \pm 0.1$ & $5.34 \pm 0.1$ & $5.24 \pm 0.1$ & $5.14 \pm 0.1$ & $5.21 \pm 0.1$ & $5.26 \pm 0.2$ & $5.24 \pm 0.1$ \\
\hline
\end{tabular}

\subsection{Microbiological Quality}

The counts of microorganisms in the analyzed "bryndza" cheese samples are in Table 3. The coliform bacteria in the "bryndza" cheese produced from pasteurized milk (producer B8) were $<1$ log $\mathrm{CFU} / \mathrm{g}$. In contrast, the counts of coliform bacteria ranged from 3.46 to $6.78 \mathrm{log}$ CFU/g in "bryndza" cheese produced from unpasteurized ewe's milk.

Table 3. Microbiological quality of bryndza cheeses (values of geomean) (log CFU/g).

\begin{tabular}{ccccccccc}
\hline & B1 & B2 & B3 & B4 & B5 & B6 & B7 & B8 \\
\hline CB & 3.77 & 3.46 & 6.01 & 6.78 & 3.72 & 6.22 & 5.27 & $<1$ \\
E & 5.35 & 7.36 & 7.35 & 7.34 & 4.59 & 7.19 & 6.47 & 2.37 \\
PL & 8.36 & 9.15 & 8.98 & 9.03 & 8.98 & 8.52 & 8.59 & 7.17 \\
PLb & 7.73 & 8.98 & 8.69 & 8.76 & 8.48 & 8.35 & 8.32 & 6.56 \\
Y & 6.62 & 6.21 & 6.26 & 4.65 & 6.52 & 5.96 & 6.19 & 5.80 \\
DG & 5.75 & 5.20 & 5.11 & 4.33 & 5.93 & 5.49 & 6.06 & 5.24 \\
\hline \multicolumn{2}{r}{ CB-coliform bacteria, E-enterococci, PL—-presumptive lactococci, PLb-presumptive lactobacilli, Y-yeasts, } \\
DG-Dipodascus geotrichum.
\end{tabular}

Enterococci in the "bryndza" cheese from pasteurized milk reached an average value of $2.37 \mathrm{log}$ $\mathrm{CFU} / \mathrm{g}$ in the monitored period. Higher counts of enterococci were found in "bryndza" cheese from unpasteurized milk in the case of coliform bacteria than in "bryndza" cheese from pasteurized milk. The counts of enterococci in these samples ranged from $4.59 \mathrm{log}$ CFU/g ("bryndza" cheese sample B5 was made from pasteurized cow's milk and unpasteurized ewe's milk) to $7.36 \log$ CFU/g.

Presumptive lactococci were dominated microbiota of "bryndza" cheese. The counts $\geq 7.17 \mathrm{log}$ $\mathrm{CFU} / \mathrm{g}$ were found in all samples. The counts of presumptive lactobacilli in bryndza cheese from pasteurized milk reached levels $6.56 \log \mathrm{CFU} / \mathrm{g}$ and from unpasteurized milk $\geq 7.73 \mathrm{log} \mathrm{CFU} / \mathrm{g}$.

Yeast counts varied from $4.65 \log \mathrm{CFU} / \mathrm{g}$ to $6.62 \log \mathrm{CFU} / \mathrm{g}$. The differences between the counts of yeasts in "bryndza" cheese from unpasteurized and pasteurized milk are not as significant as in the case of other groups of monitored microorganisms. Species Dipodascus geotrichum (before Geotrichum candidum) was dominated yeast.

\subsection{Analysis of VOC}

The VOC of different chemical natures and varied sensory descriptors were separated by e-nose, based on head-space gas chromatography with a flame-ionization detector. The twenty VOCs were identified as sensors (markers) with D $>0.900$ (Table 4). The aroma profiles of "bryndza" cheese were dominated by esters (7), aldehydes (4), alcohols (4), free fatty acids (2), ketones (2), and one monoterpene. 
Table 4. Volatile organic compounds in bryndza cheese determined by electronic nose (e-nose) with $\mathrm{D}>0.900$.

\begin{tabular}{|c|c|c|c|c|}
\hline \multicolumn{2}{|c|}{ Volatile Organic Compounds } & $\begin{array}{l}\text { Kovats' Retention } \\
\text { Index DB-5 } \\
\text { Column }\end{array}$ & $\begin{array}{l}\text { Kovats' Retention } \\
\text { Index DB-1701 } \\
\text { Column }\end{array}$ & Sensory Descriptor ${ }^{1}$ \\
\hline \multirow{2}{*}{ Ketones } & 2-butanone & 594 & 690 & \multirow{2}{*}{$\begin{array}{l}\text { butter, cheese, chemical, chocolate, } \\
\text { ethereal, gaseous } \\
\text { butter, caramelized, creamy, fruity, } \\
\text { pineapple, spirit }\end{array}$} \\
\hline & 2,3-butanonedione & 589 & 690 & \\
\hline \multirow{5}{*}{ Aldehyde } & propanal & 489 & 579 & \multirow{5}{*}{$\begin{array}{c}\text { ethereal, plastic, pungent, solvent } \\
\text { chocolate, green, malty, pungent } \\
\text { citrus, fatty, fruity, green, smoky } \\
\text { brunt, fruity, green, toasted, spicy, } \\
\text { malty, pungent } \\
\text { almond, bread, sweet }\end{array}$} \\
\hline & butanal & 578 & 668 & \\
\hline & heptanal & 901 & 986 & \\
\hline & 2-methyl propanal & 522 & 626 & \\
\hline & furfural & 836 & 978 & \\
\hline \multirow{6}{*}{ Esters } & ethyl acetate & 614 & 677 & \multirow{6}{*}{$\begin{array}{c}\text { acidic, butter, caramelized, fruity, } \\
\text { orange, pineapple, pungent, } \\
\text { solvent, ethereal, sweet } \\
\text { banana, bitter, ethereal, green, } \\
\text { strong, fruity, pear, pineapple, } \\
\text { sweaty, sweet } \\
\text { acetone, banana, bubblegum, } \\
\text { caramelized, fruity, pineapple, } \\
\text { strawberry, sweet } \\
\text { banana, fresh, fruity, pear, sweet } \\
\text { acetone, fruity, solvent } \\
\text { apple, chewing gum, fruity, } \\
\text { solvent, spirit }\end{array}$} \\
\hline & butyl acetate & 813 & 879 & \\
\hline & ethyl butanoate & 800 & 865 & \\
\hline & \multirow{3}{*}{$\begin{array}{l}\text { isoamyl acetate } \\
\text { ethyl propanoate } \\
\text { methyl 2-methyl } \\
\text { butanoate }\end{array}$} & 876 & 945 & \\
\hline & & 710 & 766 & \\
\hline & & 774 & 840 & \\
\hline \multirow{4}{*}{ Alcohols } & 2-methyl propanol & 626 & 736 & \multirow{4}{*}{$\begin{array}{l}\text { alcoholic, bitter, chemical, glue, } \\
\text { leek, lecorice, solvent, winey } \\
\text { alcoholic, ethereal } \\
\text { cheese, fermented, fruity, } \\
\text { medicinal } \\
\text { dry, floral, fruity, grassy, green, } \\
\text { herbaceous, mild woody }\end{array}$} \\
\hline & 2-propanol & 500 & 602 & \\
\hline & n-butanol & 664 & 779 & \\
\hline & 1-hexanol & 868 & 980 & \\
\hline \multirow{2}{*}{$\begin{array}{l}\text { Free Fatty } \\
\text { Acids }\end{array}$} & propanoic acid & 739 & 889 & \multirow{2}{*}{$\begin{array}{l}\text { acidic, pungent, rancid, soy } \\
\text { cheese, fatty, goat, pungent, } \\
\text { rancid, sweaty }\end{array}$} \\
\hline & hexanoic acid & 996 & 1186 & \\
\hline Monoterpenes & limonene & 1049 & 1073 & citrus, fruity, minty, orange, peely \\
\hline
\end{tabular}

The dataset of e-nose was in the two-dimensional (2D) PCA plot. The first two principal components accounted for over $90 \%$ of total variance indicating that the first two PCs are sufficient enough to explain the total variance of the dataset. When the samples overlap or close to each other, it means they have a similar aroma as it is shown in Figure 1, 40 "bryndza" pieces of cheese from 8 producers divided into 5 groups according to the month of production in PC1 (76.25\%). The samples from the May group were far away from the September group, which means that they have significantly different aromas and simultaneously, May and September groups of samples are surrounded by June, July, and August. In general, the PCA result suggested that the e-nose can properly characterize the samples of "bryndza" cheese. 


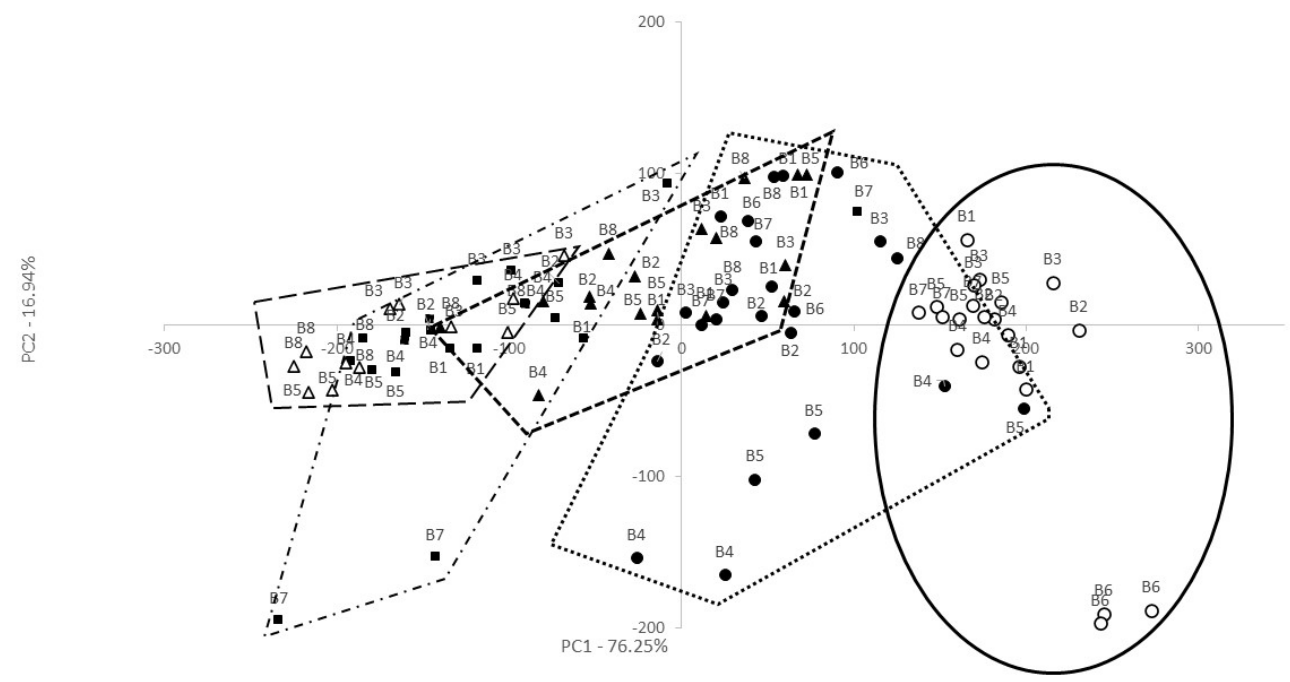

Figure 1. Projection of "bryndza" cheese from 8 producers (B1-8) onto the space defined by the first two principal components (PC1/PC2) based on the e-nose results. Sample groups according to the month: $\bigcirc$-May, •-June, $\mathbf{\Delta - J u l y , ~}$ - -August, $\Delta$-September.

Based on the qualitative analysis of HS-SPME/GC-MS results, a total of 24 VOCs were identified from "bryndza" cheese produced by 8 producers including alcohols (7), free fatty acids (6), esters (4), aldehydes and ketones (4), one monoterpene and one oxime in this study. Data in Table 5 shown the average chemical composition of samples produced during 2019 (from May to September). The compounds with the highest relative contents in "bryndza" were isoamyl alcohol (2.86-10.6\%), acetoin (6.16-20.7\%), acetic acid (7.42-11.3\%), butanoic acid (ND-5.88\%), and methoxy-phenyl-oxime (3.74-8.54\%).

Table 5. Average chemical composition (TIC $\%$ Area ${ }^{1}$ of the bryndza cheese from producers B1-8 produced from May to September 2019 obtained by gas chromatography (GC-MS) analysis.

\begin{tabular}{|c|c|c|c|c|c|c|c|c|c|}
\hline \multicolumn{2}{|c|}{ Volatile Organic Compounds (TIC\% Area) } & B1 & B2 & B3 & B4 & B5 & B6 & B7 & B8 \\
\hline \multirow{7}{*}{ Alcohols } & isoamyl alcohol ${ }^{\mathrm{a}, 2}$ & 5.20 & 4.64 & 4.07 & 3.22 & 10.6 & 4.34 & 2.86 & 4.56 \\
\hline & 2,7-dimethyl-4,5-octandiol ${ }^{\text {a }}$ & 1.19 & 1.39 & 1.01 & 1.06 & $\mathrm{ND}^{3}$ & 0.93 & 0.72 & 0.94 \\
\hline & 2,3-butanediol & 1.19 & 1.60 & 3.30 & 3.94 & 2.55 & 2.03 & 1.40 & 2.56 \\
\hline & $\beta$-phenyl ethanol ${ }^{\mathrm{a}, \mathrm{b}}$ & 0.72 & 0.75 & 6.73 & 0.97 & 2.40 & 1.52 & 1.07 & 6.82 \\
\hline & dl-erythro-1-phenyl-1,2-propanediol ${ }^{\text {a }}$ & 1.78 & 0.64 & 0.71 & 0.60 & ND & ND & ND & ND \\
\hline & 1-methoxy 2-propanol & ND & ND & ND & ND & 1.59 & ND & ND & ND \\
\hline & 2-butanol & ND & ND & ND & 12.36 & ND & ND & ND & ND \\
\hline Aldehyde & Benzaldehyde $^{a}$ & 2.04 & 0.79 & 0.55 & 0.48 & ND & ND & 0.62 & ND \\
\hline \multirow{3}{*}{ Ketones } & acetoin & 6.16 & 11.3 & 11.8 & 15.2 & 18.5 & 20.7 & 18.9 & 10.6 \\
\hline & 2,3-butanedione ${ }^{\mathrm{b}}$ & ND & 2.55 & 3.55 & 1.95 & 2.39 & 1.31 & 3.15 & 3.24 \\
\hline & 2-butanone & ND & ND & ND & 16.47 & ND & ND & 2.77 & ND \\
\hline \multirow{6}{*}{$\begin{array}{c}\text { Free fatty } \\
\text { acids }\end{array}$} & acetic acid & 7.42 & 10.4 & 9.87 & 11.3 & 9.42 & 7.97 & 8.95 & 8.74 \\
\hline & butanoic acid $^{a}$ & 4.33 & 4.02 & 2.00 & 1.80 & 2.45 & 3.01 & 5.88 & ND \\
\hline & pentanoic acid $^{\text {a }}$ & 1.15 & 1.50 & 1.00 & ND & 0.74 & 0.74 & 1.37 & 2.69 \\
\hline & hexanoic acid ${ }^{a}$ & 3.71 & 4.04 & 3.74 & 2.85 & 3.96 & 3.94 & 6.98 & 3.66 \\
\hline & octanoic acid & ND & 1.76 & 1.97 & 1.37 & 4.18 & 3.55 & 4.23 & 1.52 \\
\hline & n-decanoic acid & ND & ND & ND & ND & 2.51 & ND & 2.37 & ND \\
\hline
\end{tabular}


Table 5. Cont.

\begin{tabular}{|c|c|c|c|c|c|c|c|c|c|}
\hline Volatile & c Compounds (TIC\% Area) & B1 & B2 & B3 & B4 & B5 & B6 & B7 & B8 \\
\hline \multirow{4}{*}{ Esters } & ethyl acetate & 3.10 & 5.26 & 6.10 & 3.63 & 3.63 & 8.07 & ND & 4.65 \\
\hline & 2-phenetyl acetate ${ }^{a, b}$ & 0.93 & 1.37 & 8.07 & 0.85 & ND & 0.60 & ND & 3.34 \\
\hline & acetoin acetate $^{a}$ & ND & 0.77 & 1.97 & ND & 1.14 & 0.90 & ND & 1.05 \\
\hline & isoamyl acetate & ND & ND & 1.76 & ND & ND & ND & ND & 3.04 \\
\hline Monoterpenes & D-limonene ${ }^{a, b}$ & 1.05 & 0.76 & 0.50 & ND & ND & ND & 0.71 & ND \\
\hline Oxime & phenyl-methoxy-oxime & 8.54 & 5.69 & 4.40 & 4.33 & 4.20 & 3.74 & 4.46 & 5.15 \\
\hline
\end{tabular}

The six compounds identified by e-nose with a D $>0.900$ with ethyl acetate, isoamyl acetate, 2-butanone, hexanoic acid, D-limonene, and 2,3-butanedione were confirmed by GC-MS in this study. Statistical analysis of variance was used to differentiate cheese by evaluation scores such as type of milk, and dairies (farm or industrial) (Table 5). Particularly type of milk had a significant influence on the amounts of identified VOC. The relative chemical composition (TIC\% Area) of 2,3-butanediol, 1-methoxy 2-propanol, 2-butanol, acetoin, 2-butanone, acetic acid, octanoic acid, $n$-decanoic acid, ethyl acetate, isoamyl acetate, and phenyl-methoxy-oxime were not significantly influenced by type of milk or dairies. Statistical analysis by the Test of Tukey's confirmed that TIC\% Area of ten compounds was influenced by type of milk. The TIC $\%$ Area of $\beta$-phenyl ethanol, 2,3-butanedione, 2-phenetyl acetate, and D-limonene was significantly influenced by dairies $(p<0.05)$.

\section{Discussion}

The quality of "bryndza" cheese is affected by many factors, such as the composition of used ewe's and cow's milk, the seasonality of ewe's milk, or the microbiota of used starter culture [31-33]. "Bryndza" cheese must have a dry matter content at least $44 \mathrm{wt} . \%$ and fat in dry matter of ewe's "bryndza" cheese should be at least $48 \mathrm{wt} . \%$ and in mixed "bryndza" cheese at least $38 \mathrm{wt} . \%$ [30].

The reason for fat, fat in dry matter and dry matter content fluctuation in "bryndza" cheese from farm dairies is that the fat content in milk is not standardized in the traditional production. It is known that the fat and dry matter content of ewe's milk changes naturally during the season [34]. Industrial dairies also use cow's milk to "bryndza" cheese production, which explains lower fat content in the "bryndza" cheese from these producers (B3 and B8). Most "bryndza" cheese samples from the industrial producer (B3) had lower dry matter content than it is in legislative requirements. The changes in the composition of ewe's milk and in the produced lump cheese, as well during the season were also reflected in the sensory properties of "bryndza" cheese.

Coliform bacteria are considered as indicators of faecal contamination or poor hygienic conditions in obtaining and processing milk into cheese or low counts of competing LAB. The counts of LAB were high in the analyzed "bryndza" samples, therefore, the coliform bacteria counts indicate poor hygiene in milk processing into cheese. The exception is the counts of coliform bacteria in the "bryndza" cheese from farmers B1 and B2. The differences in the counts of coliform bacteria between "bryndza" cheese made from unpasteurized and pasteurized milk are in line with the results of other studies in this area [35]. Coliform bacteria in "bryndza" cheese have also been found by other authors $[7,32,33]$.

Higher counts of enterococci were found in "bryndza" cheese samples made from unpasteurized ewe's milk on farms. Some authors [36] even found higher counts of enterococci (8.0 log CFU/g) in "bryndza" cheese made from raw ewe's milk in comparison with our results. In contrast, there are some results with very similar counts of enterococci (5.11-5.85 log CFU/g) in "bryndza" cheese made from raw and pasteurized milk in published studies [33]. The presence of enterococci in food may not always indicate faecal contamination, but rather, a violation of hygiene and sanitation principles. In the case of some food (cheese and fermented meat products), enterococci are added into them in a 
targeted way to improve organoleptic properties [37]. Enterococci and yeast in ewe's cheese made from raw milk contribute to the formation of acetic acid esters [38].

Various genera and species of LAB are present in the microbiota of raw ewe's milk. Their counts gradually increase during the production of lump cheese and "bryndza" cheese [7]. Starter culture, which is not so varied in genus and species, must be added into the milk after pasteurization to achieve lactic acidification. "Bryndza" cheese made from pasteurized milk may have lower counts of lactic acid bacteria, especially lactobacilli, as it is evidenced by our results and the works of other authors [32]. LAB break down lactose into lactic acid and various aroma compounds such as diacetyl, acetoin, acetaldehyde, or acetic acid [39]. However, they contribute very little to the lipolysis of milk fat. LAB cause the degradation of casein fractions into small peptides and free amino acids by the production of proteinases and peptidases. Amino acids can change into various alcohols, aldehydes, acids, esters, and sulfur compounds, which contribute to the specific aroma of the cheese [40].

Yeast is a natural microbiota of "bryndza" cheese and acts in the secondary stage of this cheese ripening. It is not surprising that the differences in yeast counts in "bryndza" cheese, made from raw and pasteurized milk, are minimal. Dipodascus geotrichum has a dominant position among yeasts in bryndza cheese. This type of yeast grows on the surface of the lump and breaks down lactates, milk fat (free fatty acids are released) and proteins (peptides and amino acids) [41,42]. Some strains of Dipodascus geotrichum are able to produce esters and various sulfur compounds, which contribute to the formation of a typical aroma and overall quality parameters of cheese [41].

$\mathrm{LAB}$, enterococci, and yeasts Galactomyces candidus $[6,7,32,43]$ play a key role in aroma development during cheese ripening. The VOCs are generated by the enzymatic degradation of amino acids in cheese, especially in cheese containing only LAB. The amino acid transamination is catalyzed by lactococci aminotransferases and this is the first step in the degradation of volatile and branched-chain amino acids, which are precursors of volatile organic compounds [44,45]. The resulting $\alpha$-ketoacids are then degraded to aldehydes, alcohols, carboxylic acids, esters, methanethiol, and other sulfur compounds [46]. The seven compounds as 2-methyl propanol, ethyl acetate, ethyl butanoate, 2-butanone, isoamyl acetate, hexanoic acid, and butane-2,3-dione were identified in this study by e-nose and gas chromatography-olfactometry, as previously described in "bryndza" cheese from Slovakia $[4,5,20,32]$. Several of the identified compounds (ethyl acetate, 2-phenyl ethyl acetate, ethyl propanoate, 2-methyl-propanol, 2-phenyl ethanol, 2,3-butanediol, 3-hydroxy-2-butanone (acetoin), 3-methyl butanol, 2,3-butanedione, acetic, butanoic, pentanoic, and octanoic acids) are known to be components of different foreign ewe's cheese as the Oscypek, Canestrato Pugliese, Fiore Sardo, Torta del Casar, Terrincho, Roncal, Manchego, Pecorino Romano [47-49]. Other identified compounds, benzaldehyde [13], 2,7-dimethyl-4,5-octanediol [50] were previously described as secondary metabolites by LAB. Passerini et al. [51] confirmed that strains of L. lactis with the citP gene and the citM-G cluster produced a larger amount of VOCs than the strains without this genetic information. Likewise, the quality differences in milk and dairy products from different grazing areas have been previously reported [52,53].

The terpenes composition (limonene, myrcene, carvone) of milk and cheese are directly transferred from ingested botanical species and free fatty acids (acetic, butanoic, pentanoic, octanoic, decanoic, and dodecanoic acids) can also be effective to trace animal management and feeding systems [54]. Fatty acids were the most abundant VOCs in the barrelled ewe's cheese (intermediate product in the production of winter bryndza) from Slovakia [4] and in the raw ewes' milk cheese Torta del Casar [47,48] or Feta cheese [52]. The free fatty acids are also precursors of methyl ketones, alcohols, lactones, and esters, so they may play an important role in the global aroma development of cheese [48]. The identified 2 -methyl propanal was previously described [55] as milk aromas. The other compounds, $n$-butanol and methoxy-phenyl-oxime were previously identified in cheese produced from pasteurization milk fermented with cultures mixed (L. bulgaricus and Streptococcus thermophilus) and with Dregea sinensis Hemsl. protease [56]. 
The e-nose technology in this study can detect the fingerprint of VOCs present in the headspace of the "bryndza" sample and "parenica" cheese previously described [22] by means of a gas chromatography principle. There are several studies in which an e-nose method containing 10 metal-oxide semiconductors for characterization of the volatile profile of French cheese types [57], Danish blue cheese [58], or Pecorino cheese were used [59]. These mentioned works used e-nose with sensors and it could not determine and identify concrete VOCs and therefore there was a need to confirm the results by GC methods.

\section{Conclusions}

The composition, microbiological quality, as well as the production of volatile organic compounds, changed during the ewe's milk season and "bryndza" cheese production by farm and industrial producers from Slovakia. The type of heat treatment of the milk, and the technology of the "bryndza" cheese production, also had an impact on the microbiological quality. There were coliform bacteria, enterococci, presumptive lactococci, presumptive lactobacilli, and yeasts detected. The key VOC were defined in "bryndza" cheese by e-nose and GC-MS. Based on the PCA result, the May samples had significantly different aromas, compared with the September samples.

Author Contributions: Conceptualization, J.Š. and M.Č.; methodology and laboratory analyses, J.Š., V.D., M.M., M.K. and M.Č.; data curation, V.D. and M.M.; writing—original draft preparation, J.Š., V.D., M.M., M.K. and M.Č.; writing-review and editing, J.Š., V.D. and M.Č. All authors have read and agreed to the published version of the manuscript.

Funding: This research was funded by the APVV-16-0244 grant "Qualitative factors affecting the production and consumption of milk and cheese".

Acknowledgments: This study was supported by Research Center AgroBioTech built in accordance with the project Building Research Center "AgroBioTech" ITMS 26220220180 and to Operational Program Research and Innovation: "Support of research activities in the ABT RC, 313011T465, co-financed by the European Regional Development Fund".

Conflicts of Interest: The authors declare no conflict of interest.

\section{References}

1. Zajác, P.; Martišová, P.; Čapla, J.; Čurlej, J.; Golian, J. Characteristics of textural and sensory properties of Oštiepok cheese. Potr. Slovak J. Food Sci. 2019, 13, 116-130. [CrossRef]

2. Šnirc, M.; Árvay, J.; Král, M.; Jančo, I.; Zajác, P.; Harangozo, Ĺ.; Benešová, L. Content of mineral elements in the traditional Oštiepok cheese. Biol. Trace Elem. Res. 2020, 196, 639-645. [CrossRef]

3. Commission Regulation (Ec) No 676/2008 of 16 July 2008 registering certain names in the Register of protected designations of origin and protected geographical indications (Ail de la Drôme (PGI), Všestarská cibule (PDO), Slovenská bryndza (PGI), Ajo Morado de Las Pedroñeras (PGI), Gamoneu or Gamonedo (PDO), Alheira de Vinhais (PGI), Presunto de Vinhais Or Presunto Bísaro de Vinhais (PGI)), L189. Off. J. Eur. Union 2008, 51, 19-20.

4. Sádecká, J.; Šaková, N.; Pangallo, D.; Koreňová, J.; Kolek, E.; Puškárová, A.; Bučková, M.; Valík, L.; Kuchta, T. Microbial diversity and volatile odour-active compounds of barrelled ewes' cheese as an intermediate product that determines the quality of winter bryndza cheese. LWT Food Sci. Technol. 2016, 70, $237-244$. [CrossRef]

5. Šaková, N.; Sádecká, J.; Lejková, J.; Puškárová, A.; Koreňová, J.; Kolek, E.; Valík, L'.; Kuchta, T.; Pangallo, D. Characterization of May bryndza cheese from various regions in Slovakia based on microbiological, molecular and principal volatile odorants examination. J. Food Nutr. Res. Slovak 2015, 54, 239-251.

6. Kačániová, M.; Nagyová, L'.; Štefániková, J.; Felšöciová, S.; Godočiková, L.; Haščik, P.; Horská, E.; Kunová, S. Characterization of bryndza cheese from different regions of Slovakia based on microbiological quality. Potr. Slovak J. Food Sci. 2020, 14, 69-75. [CrossRef]

7. Pangallo, D.; Šaková, N.; Koreňová, J.; Puškárová, A.; Kraková, L.; Valík, L.; Kuchta, T. Microbial diversity and dynamics durnig the production of May bryndza cheese. Int. J. Food Microbiol. 2014, 170, 38-43. [CrossRef] 
8. Ozturkoglu-Budak, S.; Wiebenga, A.; Bron, P.A.; de Vries, R.P. Protease and lipase activities of fungal and bacterial strains derived from an artisanal raw ewe's milk cheese. Int. J. Food Microbiol. 2016, 237, 17-27. [CrossRef]

9. Čaplová, Z.; Pangallo, D.; Kraková, L.; Puškárová, A.; Drahovská, H.; Bučková, M.; Koreňová, J.; Kuchta, T. Detection of genes prtP, pepN, pepX and bcaT involved in formation of aroma-active compounds in lactic acid bacteria from ewes' cheese. J. Food Nutr. Res. Slovak 2018, 57, 195-200.

10. Yvon, M.; Rijnen, L. Cheese flavor formation by amino acid catabolism. Int. Dairy J. 2001, 11, $185-201$. [CrossRef]

11. Dias, B.; Weimer, B. Conversion of methionine to thiols by Lactococci, Lactobacilli, and Brevibacteria. App. Environ. Microbiol. 1998, 64, 3320-3326. [CrossRef]

12. Dias, B.; Weimer, B. Purification and characterization of L-Methionine g-lyase from Brevibacterium linens BL2. App. Environ. Microbiol. 1998, 64, 3327-3331. [CrossRef]

13. Rijnen, L.; Delacroix-Buchet, A.; Demaizieres, D.; Le Quéré, J.L.; Gripon, J.C.; Yvon, M. Inactivation of lactococcal aromatic aminotransferase prevents the formation of floral aroma compounds from aromatic amino acids in semi-hard cheese. Int. Dairy J. 1999, 9, 877-885. [CrossRef]

14. Bourdat-Deschamps, M.; Le Bars, D.; Yvon, M.; Chapot-Chartier, M.P. Autolysis of Lactococcus lactis AM2 stimulates the formation of certain aroma compounds from amino acids in a cheese model. Int. Dairy J. 2004, 14, 791-800. [CrossRef]

15. Nierop-Groot, M.N.; de Bont, J.A.M. Conversion of phenylalanine to benzaldehyde initiated by an aminotransferase in Lactobacillus plantarum. App. Environ. Microbiol. 1998, 64, 3009-3013. [CrossRef]

16. Nierop-Groot, M.N.; de Bont, J.A.M. Involvement of manganese in conversion of phenylalanine to benzaldehyde by lactic acid bacteria. App. Environ. Microbiol. 1999, 65, 5590-5593. [CrossRef]

17. González-Martín, M.I.; Vivar-Quintana, A.M.; Revilla, I.; Salvador-Esteban, J. The determination of fatty acids in cheeses of variable composition (cow, ewe's, and goat) by means of near infrared spectroscopy. Microchem. J. 2020, 156, 104854. [CrossRef]

18. Signorelli, F.; Contarini, G.; Annicchiarico, G.; Napolitano, F.; Orrú, L.; Catillo, G.; Haenlein, G.F.W.; Moioli, B. Breed differences in sheep milk fatty acid profiles: Opportunities for sustainable use of animal genetic resources. Small Rumin. Res. 2008, 78, 24-31. [CrossRef]

19. Erbay, Z.; Koca, N. Effects of using whey and maltodextrin in white cheese powder production on free fatty acid content, nonenzymatic browning and oxidation degree during storage. Int. Dairy J. 2019, 96, 1-9. [CrossRef]

20. Sádecká, J.; Kolek, E.; Pangallo, D.; Valík, L.; Kuchta, T. Principal volatile odorants and dynamics of their formation during the production of May Bryndza cheese. Food Chem. 2014, 150, 301-306. [CrossRef]

21. Boltar, I.; Čanžek Majhenič, A.; Jarni, K.; Jug, T.; Bavcon Krajl, M. Research of volatile compounds in cheese affected by different technological parameters. J. Food Nutr. Res. Slovak 2019, 58, 75-84.

22. Štefániková, J.; Nagyová, V.; Hynšt, M.; Vietoris, V.; Martišová, P.; Nagyová, L'. Application of electronic nose for determination of Slovak cheese authentication based on aroma profile. Potr. Slovak J. Food Sci. 2019, 13, 262-267. [CrossRef]

23. ISO. Cheese-Determination of Fat Content_-Van Gulik Method. International Organization for Standardization; ISO 3433:2008; International Organization for Standardization: Geneva, Switzerland, 2008.

24. ISO. Cheese and Processed Cheese Determination of the Total Solids Content (Reference Method); ISO 5534:2004; International Organization for Standardization: Geneva, Switzerland, 2004.

25. ISO. Microbiology of Food and Animal Feeding Stuffs_Preparation of Test Samples, Initial Suspension and Decimal Dilutions for Microbiological Examination-Part 5: Specific rules for the Preparation of Milk and Milk Products; ISO 6887-5:2010; International Organization for Standardization: Geneva, Switzerland, 2010.

26. ISO. Microbiology of Food and Animal Feeding Stuffs-Horizontal Method for the Enumeration of Coliforms-Colony-Count Technique; ISO 4832:2006; International Organization for Standardization: Geneva, Switzerland, 2006.

27. ISO. Microbiology of Food and Animal Feeding Stuffs. Horizontal Method for the Enumeration of Yeasts and Moulds. Part 1: Colony Count Technique in Products with Water Activity Greater than 0.95; ISO 21527-1:2010; International Organization for Standardization: Geneva, Switzerland, 2010.

28. ISO. Fermented Milk Products—Bacterial Starter Cultures—Standard of Identity; ISO 27205:2010; International IDF Standard: Brussels, Belgium, 2010. 
29. Tomáška, M.; Čaplová, Z.; Sádecká, J.; Šoltys, K.; Kopuncová, M.; Budiš, J.; Drončovský, M.; Kolek, E.; Koreňová, J.; Kuchta, T. Microorganisms and volatile aroma-active compounds in "nite" and "vojky" cheeses. J. Food Nutr. Res. Slovak 2019, 58, 187-200.

30. Regulation no. 343/2016 of the Ministry of Agriculture and Rural Development of the Slovak Republic of 8 December 2016 on Certain Dairy Products. Available online: https://www.slov-lex.sk/pravne-predpisy/SK/ ZZ/2016/343/ (accessed on 6 July 2020).

31. Planý, M.; Kuchta, T.; Šoltýs, K.; Semes, T.; Pangallo, D.; Siekel, P. Metagenomic analysis of Slovak bryndza cheese using nextgeneration 16SrDNA amplicon sequencing. Nova Biotechnol. Chim. 2016, 15, 23-34. [CrossRef]

32. Sádecká, J.; Čaplová, Z.; Tomáška, M.; Šoltys, K.; Kopuncová, M.; Budiš, J.; Drončovský, M.; Kolek, E.; Koreňová, J.; Kuchta, T. Microorganisms and volatile aroma-active compounds in bryndza cheese produced and marketed in Slovakia. J. Food Nutr. Res. Slovak 2019, 58, 382-392.

33. Semjon, B.; Reitznerová, A.; Poláková, Z.; Výrostková, J.; Mal'ová, J.; Koréneková, B.; Dudriková, E.; Lovayová, V. The effect of traditional production methods on microbial, physico-chemical and sensory properties of Slevenska bryndza Pretected Geographical Indication cheese. Int. J. Dairy Technol. 2018, 71, 709-716. [CrossRef]

34. Dudrikova, E. Hygienic and Technological Aspects of the Collection and Processing of Sheep's Milk into the Mountain Conditions in Slovakia, 1st ed.; University of Veterinary Medicine and Pharmacy: Košice, Slovakia, 2011; p. 121. (In Slovak)

35. Martin, N.H.; Trmčić, A.; Hsieh, T.H.; Boor, K.J.; Wiedmann, M. The evolving role of coliforms as indicators of unhygienic processing conditions in dairy foods. Front. Microbiol. 2016, 7, 1-8. [CrossRef]

36. Vrabec, M.; Lovayová, V.; Dudriková, K.; Gallo, J.; Dudriková, E. Antibiotic reistance and prevalence of Enterococcus sp. and Escherichia coli isolated from bryndza cheese. Ital. J. Anim. Sci. 2015, 4, 609-614.

37. Cocolin, L.; Foschino, R.; Comi, G.; Grazia Fortina, M. Description of the bacteriocins produced by two strains of Enterococcus faecium isolated from Italian goat milk. Food Microbiol. 2007, 24, 752-758. [CrossRef]

38. Liu, S.Q.; Holland, R.; Crow, V.L. Esters and their biosynthesis in fermented dairy products: A review. Int. Dairy J. 2004, 14, 923-945. [CrossRef]

39. Smit, G.; Smit, B.A.; Engels, W.J.M. Flavour formation by lactic acid bacteria and biochemical flavour profiling of cheese products. FEMS Microb. Rev. 2005, 29, 591-610. [CrossRef]

40. Van Kranenburg, R.; Kleerebezem, M.; van Hylckama Vlieg, J.E.T.; Ursing, B.M.; Boekhorst, J.; Smit, B.A.; Ayad, E.H.E.; Smit, G.; Siezen, R.J. Flavour formation from amino acids by lactic acid bacteria: Predictions from genome sequence analysis. Int. Dairy J. 2002, 12, 111-121. [CrossRef]

41. Koňuchová, M.; Liptáková, D.; Šípková, A.; Valík, L'. Role of Geotrichum candidum in Dairy Industry. Chem. Listy 2016, 110, 491-497.

42. Jaster, H.; Judacewski, P.; Ribeiro, J.C.B.; Zielinski, A.A.F.; Demiate, I.M.; Los, P.R.; Alberti, A.; Nogueira, A. Quality assessment of the manufacture of new ripened soft cheese by Geotrichum candidum: Physico-chemical and technological properties. Food Sci. Technol. 2018, 39, 50-58. [CrossRef]

43. Kačániová, M.; Kunová, S.; Štefániková, J.; Felšöciová, S.; Godočíková, L.; Horská, E.; Nagyová, L'; Haščík, P.; Terentjeva, M. Microbiota of the traditional Slovak sheep cheese "Bryndza". J. Microbiol. Biotechnol. Food Sci. 2019, 9, 482-486. [CrossRef]

44. Yvon, M.; Thirouin, S.; Rijnen, L.; Fromentier, D.; Gripon, J.C. An aminotransferase from Lactococcus lactis initiates conversion of amino acids to cheese flavor compounds. App. Environ. Microbiol. 1997, 63, 414-419. [CrossRef] [PubMed]

45. Tanous, C.; Gori, A.; Rijnen, L.; Chambellon, E.; Yvon, M. Pathways for $\alpha$-ketoglutarate formation by Lactococcus lactis and their in amino acid catabolism. Int. Dairy J. 2005, 15, 759-770. [CrossRef]

46. Savijoki, K.; Ingmer, H.; Varmanen, P. Proteolytic systems of lactic acid bacteria. App. Microbiol. Biotechnol. 2006, 71, 394-406. [CrossRef]

47. Delgado, F.J.; González-Crespo, J.; Cava, R.; García-Parra, J.; Ramírez, R. Characterization of the volatile profile of a Spanish ewe raw milk soft cheese P.D.O. Torta del Casar during ripening by SPME-GC-MS. Food Chem. 2010, 118, 182-189. [CrossRef]

48. Delgado-Martínez, F.J.; Carrapiso, A.I.; Contador, R.; Rosario Ramírez, M. Volatile compounds and sensory changes after high pressure processing of mature "Torta del Casar" (raw ewe's milk cheese) during refrigerated storage. Innov. Food Sci. Emerg. Technol. 2019, 52, 34-41. [CrossRef] 
49. Majcher, M.A.; Goderska, K.; Pikul, J.; Jeleń, H.H. Changes in volatile, sensory and microbial profiles during preparation of smoked ewe cheese. J. Sci. Food Agric. 2011, 91, 1416-1423. [CrossRef]

50. Nájera-Domínguez, C.; Gutiérrz-Méndez, N.; Nevárez-Moorillon, G.; Caro-Canales, I. Comparison of volatile compounds produced by wild Lactococcus lactis in miniature Chihuahua-type cheeses. Dairy Sci. Technol. 2015, 94, 499-516. [CrossRef]

51. Passerini, D.; Laroute, V.; Coddeville, M.; Le Bourgeois, P.; Loubiere, P.; Ritzenthaler, P.; Cocaign-Bousquet, M.; Daveran-Mingot, M.L. New insights into Lactococcus lactis diacetyl- and acetoin producing strains isolated from diverse origins. Int. J. Food Microbiol. 2013, 160, 329-336. [CrossRef]

52. Bozoudi, D.; Kondyli, E.; Claps, S.; Hatzikamari, M.; Michaelidou, A.; Biliaderis, C.G.; Litopoulou-Tzanetaki, E. Compositional characteristics and volatile organic compounds of traditional PDO feta cheese made in two different mountainous areas of Greece. Int. J. Dairy Technol. 2018, 71, 673-682. [CrossRef]

53. Iussig, G.; Renna, M.; Gorlier, A.; Lonati, M.; Lussiana, C.; Battaglini, L.M.; Lombardi, G. Browsing ratio, species intake, and milk fatty acid composition of goats foraging on alpine open grassland and grazable forestland. Small Rumin. Res. 2015, 132, 12-24. [CrossRef]

54. Moran, L.; Aldezabal, A.; Aldai, N.; Barron, L.J.R. Terpenoid traceability of commercial sheep cheeses produced in mountain and valley farms: From pasture to mature cheeses. Food Res. Int. 2019, 126, 108669. [CrossRef]

55. Cadwallader, K. Instrumental measurement of milk flavour and colour. In Improving the Safety and Quality of Milk, 1st ed.; Griffiths, M.W., Ed.; Woodhead Publishing: New York, NY, USA, 2010; Volume 2, pp. 181-206.

56. Wang, H.; Wang, Y.; Huang, A. Influence of Dregea sinensis Hemsl. protease on the quality of mozzarella cheese from buffalo milk. Emir. J. Food Agric. 2017, 29, 539-546. [CrossRef]

57. Ghasemi-Varnamkhasti, M.; Mohammad-Razdari, A.; Yoosefian, S.H.; Izadi, Z.; Siadat, M. Aging discrimination of French cheese types based on the optimization of an electronic nose using multivariate computational approaches combined with response surface method (RSM). LWT 2019, 111, 85-98. [CrossRef]

58. Trihaas, J.; Vognsen, L.; Nielsen, P.V. Electronic nose: New tool in modelling the ripening of Danish blue cheese. Int. Dairy J. 2005, 15, 679-691. [CrossRef]

59. Cevoli, C.; Cerretani, L.; Gori, A.; Caboni, M.F.; Gallina Toschi, T.; Fabbri, A. Classification of Pecorino cheeses using electronic nose combined with artificial neural network and comparison with GC-MS analysis of volatile compounds. Food Chem. 2011, 129, 1315-1319. [CrossRef] 